\title{
How to Regulate Cooperatives in the EU?
}

\author{
A Theory of Path Dependency
}

Ger J.H. van der Sangen*

\section{Introduction}

The cooperative as an economic concept and legal business form goes back to the midst of the nineteenth century. It is widely acknowledged that the 1844 established 'Rochdale Equitable Pioneers' was the first consumer cooperative, promoted by philanthropist Robert Owen. Since the founding of the Rochdale Equitable Pioneers, the concept of the cooperative showed endemic developments in Germany, where banking cooperatives based on the ideas of Raiffeisen and Schulze-Delitzsch as well as agricultural cooperatives emerged - followed later with a similar pattern in the Netherlands, while earlier in France socialist rooted worker cooperatives as well as agricultural cooperatives developed. By the end of the nineteenth century and the beginning of the twentieth century, the cooperative as a legal business form had been addressed by legislators and incorporated in private law by providing statutes on cooperative law. Meanwhile, the stock company rapidly rose to the occasion and has dominated the economic and company law arena ever since. The cooperative as an economic and legal construct lost much of its appeal after the Second World War, as was clearly illustrated by Kalmi, ${ }^{1}$ who demonstrated that the cooperative after the Second World War vanished from economic text books as an alternative vis-à-vis the investor-owned firm. Also in legal scholarship, the cooperative has not been able to equal the attention for the stock company, privately held or listed, and different types of partnerships. That is not to say that cooperatives did not provide in societal and economic needs. On the contrary, strong cooperatives developed in the previous century, notably in agriculture and banking including mutual insurance compa-

* Dr Ger J.H. van der Sangen is Associate Professor Company Law and Securities Law at Tilburg Law School, Department Business Law. He was part of the research team of the EU-funded project Support for Farmers' Cooperatives. He would like to express his gratitude to all the members of the research team for sharing their insights and discussions during conference meetings in Brussels (November 2011 and 2012) and in Helsinki (June 2012), in particular J. Bijman, C. Gijselinckx, G. Hendrikse, C. Iliopoulos and K. Poppe.

1. Kalmi 2006. nies. $^{2}$ On a smaller scale, cooperatives were used for housing in condominium, for retail shops and for workers' participation. ${ }^{3}$

The case for the cooperative as a viable business form regained momentum in the EU policy debate with the EU Action Plan $2003^{4}$ and the introduction of the SCE Statute in $2003,{ }^{5}$ the outbreak of the financial and economic crisis in 2008 - arguing that cooperatives showed a different attitude towards risks than their investorowned counterparts in banking and provided a more sustainable business model ${ }^{6}$ - and with the endorsement of the cooperative business concept by the United Nations and the International Labour Organization in 2012. The cooperative was considered to also play an important? role in the so-called 'social economy' of the EU. ${ }^{7}$ Directed from a different angle, the cooperative was also considered to have a positive effect on overcoming market failures in the food process chain in Europe and in agriculture in general and in the development of regions and the environment as part of the Common Agricultural Policy. ${ }^{8}$ It is in this respect that the key question of this article will be addressed: if the sound development of cooperatives as an alternative legal business form vis-à-vis investor-owned firms is considered a policy instrument to enhance societal business activities - notably in the field of agriculture and social economy - it raises the question how cooperatives should be regulated to fulfil their function in this respect. In particular, the question should be addressed

2. See Hansmann 1996, focusing on the developments in the US, as well as Iliopoulos 2012. For Europe, see Bijman et al. 2012 and Van Bekkum 2009.

3. Dow 2003

4. EU Corporate Governance Action Plan, $\operatorname{COM(2003)} 284$ of 21 May 2003, preceded by the Report of the High Level Group of Company Law Experts on a Modern Regulatory Framework for Company Law in Europe (Winter Report), 4 November 2002, referring to the role of cooperatives.

5. Council Regulation (EC), No 1435/2003 of 22 July 2003 on the Statute for a European Cooperative Society (SCE), OJ L 207/1 of 18 August 2003, accompanied by Council Directive 2003/72/EC of 22 July 2003, supplementing the Statute for a European Cooperative Society with regard to the involvement of employees, OJ L 207 of 18 August 2003. See also Communication from the Commission to the Council and the European Parliament, The European Economic and Social Committee and the Committee of Regions on the promotion of co-operative societies in Europe, $\operatorname{COM}(2004)$ 18, Brussels, 23 February 2004.

6. In this vein, Wyman 2008.

7. <http://ec.europa.eu/enterprise/policies/sme/promotingentrepreneurship/social-economy/>.

8. See Bijman et al. 2012, as well as the special issue of: 85 Annals of Public and Cooperative Economics 4, 2014. 
whether there is a case for enhancing national cooperative laws and whether initiatives at EU level are induced and helpful in this respect.

In order to answer these questions, the phenomenon of path dependency will be addressed in view of the harmonization process of cooperative law in the $\mathrm{EU}$ in order to get a better insight and understanding of past and future national and EU law-making with regard to cooperatives. The main focus in this article is on business organizational law. Aspects of competition law and tax law will be touched upon only briefly and where relevant. The question is raised whether and how this legislative harmonization process has an impact on cooperators in their efforts at setting up and maintaining efficient cooperative organizations and whether in this respect the SCE Statute is a helpful tool to facilitate the enhancement of national statutes on cooperatives as well as to provide the legal infrastructure to facilitate crossborder cooperation amongst and reorganizations of cooperatives in the EU.

The key argument presented in this article is that due to strong tendencies of path dependency a top-down approach of EU law-making was and is not a feasible option. The cooperative as a multifaceted institution requires a multifaceted approach, taking into account the historical legislative development of distinctive jurisdictions as well as the historical economic development of cooperative organizations in their specific jurisdiction. However, the existence of path dependency and the lack of regulatory arbitrage as well as regulatory competition prevent the market from generating efficient model statutes for cooperatives taking into account the specific needs of cooperatives and their co-operators.

\section{Path Dependency}

The concept of path dependency has been used in economics, mathematics, sociology, biology and in historical and legal scholarship, notably by law and economic scholars. The concept of path dependency goes beyond the general understanding that 'history matters'. To restrict the understanding of path dependency to a mere historical perspective would be a misconception of its claim. Path dependency understood in this way may only describe how a certain status quo has been achieved but not why the status quo remains unchanged, even when the status quo provides solutions that are ostensibly inefficient, while at the same time other solutions available are proven to be more efficient. A theory of path dependency therefore not only explains which drivers caused the status quo and why it pertains but also provides insights into the drivers that hamper future measures to change the status quo for the better. For the argument in this article, it is fruitful to use the concept of path dependency as described by Bebchuk and Roe. ${ }^{9}$ They have determined two sources of path dependency linked to sets of legal rules and institutions. The first source of path dependency in their view is structure driven, for example related to the initial ownership structure of companies in a specific jurisdiction that had a predominant influence on the type of laws and norms applied to this type of company. Path dependency has the effect of hampering innovative future law-making in case the existing rules are inefficient because of efficiency effects and internal rentseeking by established users. ${ }^{10}$ In general, Bebchuk and Roe claim that as long as those who can block structural transformation do not bear the full costs of persistence or do not capture the full benefits of an efficient move inefficient structures that are already in place might persist contrary to what is expected in a purely Coasian world. This is exactly what happened in the stages of the development of cooperatives in the EU, which will be demonstrated below.

The second source of path dependency Bebchuk and Roe identified is rule driven. Existing rules pertain because of efficiency effects and the influence of interest groups politics. Rules that are efficient depend on existing patterns of corporate structures and institutions (both formal and informal norms). Confronted with suboptimal rules, incorporators acting rationally would opt out by choosing an efficient set of rules, if available under the condition that the benefits exceed the switching costs. However, this is not what is happening with cooperatives in the $\mathrm{EU}$, although the possibility to use different corporate charters - in competition with national business forms as well as in competition with business forms, including foreign cooperative charters from other Member States - has been well established and founded in the freedom of movement of Articles 49 and 54 TFEU and the extensive case law of the European Court of Justice in this respect. Also no significant vertical regulatory arbitrage between domestic cooperatives statutes and the SCE Statute has been accounted for based on the 25 established SCEs in the European Union. ${ }^{11}$

In their analysis of interest groups politics, Bebchuk and Roe explain why the inefficient legal rules and institutions resulting from interest group politics might vary among countries due to the initial patterns of corporate ownership. In their view, global products markets, the capital market and the market for corporate control may

9. Bebchuk \& Roe 1999

10. Bebchuk \& Roe 1999, p. 2.

11. Vertical regulatory arbitrage is defined here as the possibility incorporators have to actively choose between domestic company statutes and supranational statutes, like the SCE Statute. However, the 25 existing SCEs in Europa have been established ex novo and with the exception of Cassia-Coop do not operate a business according to cooperative economic principles but operate as shell and shelf-companies. To be sure, horizontal regulatory arbitrage is defined here as the possibility for entrepreneurs to actively choose to incorporate or to reincorporate a company in another Member State. However, cooperatives do not enter into cross-border selection of business forms but stick to the available domestic legal business forms. See Bijman, Pyykkönen \& Ollila 2012. See on the concept of vertical and horizontal regulatory arbitrage Essers et al. 2011, p. 190 and Roe 2003, p. 588. 
lead to convergence of corporate governance to some extent, but they cannot be expected to eliminate path dependency. Their claim was projected on stock-listed investor-owned firms. Since only large multinational cooperatives compete on global products markets, since only a small proportion of cooperatives depend on equity capital raised on capital markets and since cooperatives are not prone to takeovers due to their legal ownership structure, ${ }^{12}$ Bebchuk and Roe's claim of persistency of path dependency is likely to hold for cooperatives even more.

\section{EU Harmonization of Company Law}

Although cooperatives are explicitly listed in the enunciation of business forms that are granted the freedom of movement throughout the European Union in Articles 49 and 54 TFEU, the legal business form of the cooperative has not been an integral part of the EU company law harmonization programme, starting in 1968 with the First EU Company Law Directive. Whereas the EU company law harmonization programme - with all its difficulties ${ }^{13}$ - was initially geared at the harmonization of public companies limited by shares and later on extended in some directives to private companies limited by shares, cooperatives were from the beginning excluded from the harmonization programme. At best, in several EU Company Law Directives the application was left to the Member States to decide. ${ }^{14}$ This left Member States ample space not to bring national cooperative law in alignment with the EU company law harmonization programme. One of the main reasons to exclude cooperatives from EU-wide harmonization was the already large variety of exponents of national cooperative statutes, ${ }^{15}$ while at the same time, when the EU company law harmonization programme started, the cooperatives appeared - with some exceptions - to be a home market oriented business form. Even today, the

12. See on this subject Bijman, Hanisch \& Van der Sangen 2014, pp. 641-661, describing seven developments in corporate governance in large cooperatives pointing out these differences to investor-owned stock-listed firms.

13. See for an overview with references Essers et al. 2011, pp. 195-204.

14. See, for example, Art. 1, para. 2, Second EU CL Directive: “The Member States may decide not to apply this Directive to (...) cooperatives (...)", Art. 1, para. 2, Third EU CL Directive: "The Member States need not apply this Directive to cooperatives (...)." The same applies to the Six EU CL Directive, due to the reference in Art. 1, para. 1 to the Third EU CL Directive. Particularly interesting in this respect is the Tenth EU $\mathrm{CL}$ Directive on cross-border mergers. The Tenth EU CL Directive applies to limited liabilities companies with share capital. However, according to Art. 3, para. 2, Tenth EU CL Directive, the Member States may decide not to apply the directive on cooperative societies even if it falls within the definition of Limited Liability Company. From this follows that cooperatives structured as associations, like in the Netherlands, do not fall within the scope of the Tenth Directive at all. No reference to cooperatives has been made in the First, Fourth, Seventh, Eighth, Ninth, Eleventh and Thirteenth EU CL Directive.

15. Fici 2013 c, p. 7, argues that "probably the only uniform rule in Europe is that on capital variability". large majority of cooperatives in the agricultural sector in the EU operate locally, regionally or nationally, with of course the exception of large internationally operating cooperatives like FrieslandCampina and Arla, to name a few. However, recent research data indicate that even these large cooperatives do not merge cross-border with other cooperatives. ${ }^{16}$ In short, a regulatory framework in the EU for harmonizing cooperative law is absent. Even future attempts to fully harmonize company law in general are no longer a high priority of the EU. ${ }^{17}$

While saying this, we have to keep in mind that the need for a full harmonization of cooperative law in the EU may be lacking urgency because cooperatives - even small ones - commonly run their business through separate subsidiaries to enter into contracts with their member suppliers/buyers or patrons. These subsidiaries are commonly incorporated as private companies limited by shares, providing the required business organizational flexibility. From recent research data, we conclude that from a business organizational point of view all Member States allow setting up cooperatives as a group of companies with the cooperative acting as the holding. ${ }^{18}$

Alongside the discussion to create a pan-European business form for primarily public companies through the introduction of the SE Statute, at the level of the European legislative institutions discussions were started to create a supra-national business form for cooperatives as well as in the form of the European Cooperative Society (SCE). The 2003 EU Corporate Governance Action Plan, COM(2003) 284 of 21 May 2003 first mentioned the need for the SCE explicitly in $\S 3.6$, in order to enhance cross-border cooperation between cooperatives from different Member States and to facilitate crossborder mergers. Also, an acclaimed objective of the SCE Statute was to approximate national cooperative laws. This was followed by a Communication of the European Commission on the promotion of cooperative societies in Europe. ${ }^{19}$ Capturing the moment after the legislative achievement of the introduction of the SE Statute, the SCE Statute was introduced with the Council Regulation (EC), No 1435/2003 of July 2003 on the Statute for a European Cooperative Society (SCE), OF L 207/1 of 18 August 2003 and accompanied by Council Directive 2003/72/EC of 22 July 2003, supplementing the Statute for a European Cooperative Society with regard to the

16. Bijman, Pyykkönen \& Ollila 2012. If cooperatives do expand their business in other Member States, this is done through takeovers or asset deals, even if the target is a former cooperative. Members of the multinational cooperatives are highly sensitive about accepting the supplying farmers of the targeted cooperative because of a potential dilution of control rights if these farmers become members of the acquiring cooperative.

17. On this matter extensively: Fici 2013b, pp. 115-151.

18. Van der Sangen 2012b and Bijman, Hanisch \& Van der Sangen 2014, pp. 641-661. Negative effects may include the loss of tax facilities or the perceived loss of effective member control, while formal legal control has been regulated in the cooperative law and their articles of association, a phenomenon described previously by Hansmann 1996, p. 11.

19. Communication from the Commission to the Council and the European Parliament, The European Economic and Social Committee and the Committee of Regions on the promotion of cooperative societies in Europe, $\operatorname{COM}(2004)$ 18, Brussels, 23 February 2004. 
involvement of employees, Of L 207 of 18 August 2003. A closer look will reveal that the creation of the SCE Statute, envisaged in the 2003 Action Plan, was based on the same legislative technique and footing as the SE Statute. More importantly, the introduction of the SCE Statute was not preceded by an extensive consultation of the cooperative sector, nor was prior research conducted at that stage into the needs of existing cooperative enterprises.

The positive effects so far of the introduction of the SCE Statute are very trivial. For example, at this moment 25 SCEs have been established of which to my knowledge only one is connected to the cooperative movement and operates in the agricultural sector. ${ }^{20}$ All 25 SCEs have been established ex novo. None of them was the result of cross-border activity (cross-border merger or seat transfer), nor the result of a conversion of an existing cooperative. To evaluate the success of the SCE Statute as well as the implementation of the SCE Statute into national law, the 2010 Report of Euricse ${ }^{21}$ meticulously described and analysed existing national regulations on cooperative law and the level of implementation of the SCE Regulation and the SCE Directive on employee involvement into national laws. One of the main conclusions of this report related to the level of approximation of national cooperative law concluded that the SCE Statute had no significant effect in this respect. Yet, the SCE Statute introduced for cooperatives several novelties, like the possibility to create a one-tier board in typically two-tier board jurisdictions, the possibility to engage into a cross-border merger and cross-border seat transfer and, finally, the possibility to create a non-using investor membership, leaving, however, the decision to actually implement this option to the Member States.

In a report of the European Commission ${ }^{22}$ summarizing the results of the evaluation of the SCE Statute, the Commission responded that a possible revision - again alongside a future revision of the SE Statute ${ }^{23}$ - was considered a feasible option, followed later with a consultation of stakeholders during a conference in April

20. Report from the Commission to the European Parliament, the Council, the European Economic and Social Committee and the Committee of the Regions, The application of Council Regulation (EC) No 1435/2003 of 22 July 2003 on the Statute for a European Cooperative Society (SCE), Brussels, 23 February 2012, COM(2012) 72 final, referring to 24 SCEs established in November 2011. According to a list of SCEs composed by Libertas - Europäisches Institut $\mathrm{GmbH}$ of 8 July 2013, there are 25 SCEs established: 9 in Slovakia, 5 in Germany, 4 in Italy, 3 in Hungary and 1 in the following states: France, Liechtenstein, the Netherlands and Sweden.

21. Euricse, Cooperatives Europe \& Ekai, Study on the implementation of the Regulation 1435/2003 on the Statute for European Cooperative Society, Trento, 5 October 2010.

22. Report of the European Commission from the Commission to the European Parliament, the Council, the European Economic and Social Committee and the Committee of the Regions, The application of Council Regulation (EC) No 1435/2003 of 22 July 2003 on the Statute for a European Cooperative Society (SCE), Brussels, 23 February 2012, $\operatorname{COM}(2012) 72$ final.

23. It is no secret that the SE Statute is not an entire EU legislative success either. See for criticism Ernst \& Young 2009, and for a company law and tax law analysis Dumoulin et al. 2005.
2012 in Brussels, where the meeting voted almost unanimously to revise the SCE Statute. However, the climate has since changed. In the November 2012 Action Plan, ${ }^{24}$ the option of revising the SCE Statute has been traded for "looking into similar measures to create more awareness of legal advisors of the benefits of the SCE Statute" in the slipstream of these measures related to the $\mathrm{SE}$ Statute.

Looking into the reasons why the SCE Statute has become no success, we are able to identify several pathdependent factors. ${ }^{25}$ As said above, the EU introduced the SCE Statute on the same legislative footing as the SE Statute through a regulation that referred immediately to national cooperative law for several issues through a 'renvoi' technique, while other issues needed mandatory implementation and optional implementation respectively. Apart from the inherent complexity to identify which rules apply to an SCE, ${ }^{26}$ as a result this legislative technique added 28 'new' business forms to the available EU menu of company charters.

Alongside the regulation, the EU produced a directive on employee involvement rooted on the same principles as the SE Directive, in particular the 'before and after' principle. ${ }^{27}$ However, the complexity of the regulation for cross-border cooperation and reorganizations for cooperative firms from different member states has been emphasized by the fact that cooperative law in the European Union has not been harmonized, while national codes on cooperative firms are rooted differently, evidencing strongly the theory of path dependency. ${ }^{28}$ To date, only 25 SCEs have been registered in the European Union and none of them were created by way of a cross-border merger, seat transfer or conversion.

With respect to the reasons for the lack of success of the SCE, it can be observed that - although the SCE Regulation seems very clear on this issue in Article 78, paragraph 1 of SCE Regulation - national legislators did not take appropriate measures at national or regional level to support an active use in practice of either national cooperatives or the SCE as a business form. In most Member States, the legislator merely confined itself to implementing the SCE Regulation and Directives as far as necessary, whilst a small number of Member States did not implement the SCE Regulation and its supplementing Directive into national law at all. ${ }^{29} \mathrm{~A}$ second reason that the SCE is not being used in practice may be based on the dichotomy between the national cooperative stat-

24. Communication from the Commission to the European Parliament, the Council, the European Economic and Social Committee and the Committee of the Regions, Action Plan: European company law and corporate governance - a modern legal framework for more engaged shareholders and sustainable companies, Strasbourg 12 November 2012, $\operatorname{COM}(2012) 740, \S 4.5$, p. 14.

25. This section is to a large extent based on Essers et al. 2011, p. 206 and 207, co-written by the author of this article together with E.C.C.M. Kemmeren.

26. See more in detail on the renvoi technique Fici 2013b, pp. 115-151.

27. See on the effects of the 'before and after'-principle Van der Sangen 2005, pp. 169-214 and Gelter 2009.

28. Van der Sangen 2010, p. 982 and the 2010 SCE-Report, pp. 78-79.

29. See Essers et al. 2011, p. 207. 
utes that follow the organizational structure of an association and which is relatively flexible, while the SCE follows the organizational structure of a company with share capital, albeit variable. Another reason may be found in the fact that the SCE is governed by different layers of legislation and provisions in the articles of association. Combined with the complex rules for employee involvement, stemming from the directive, this technique makes the SCE Statute highly inaccessible for practitioners as well as end-users. It seems that the facilities for cross-border mergers and seat transfer did not meet the demands of cooperatives in practice. Finally, the tax implications of the SCE Statute were not considered. ${ }^{30}$

The benefits of the SCE had to be found mainly in the field of facilitating cross-border legal mergers and seat transfers and cross-border cooperation between cooperatives from different Member States, as well as the opportunity to opt for a one-tier board structure in a two-tier board jurisdiction, and the novelty of non-user membership with limited voting rights, in order to facilitate direct investments of equity providers. With regard to the facility of cross-border legal mergers, it seems that the demand for this facility has been absent, in particular because the regulation forces cooperatives wishing to merge to establish an SCE. It is worth noting at this point that the implemented 10th Directive on crossborder legal mergers for private companies limited by share $^{31}$ does not provide for facilities for cross-border legal mergers between cooperatives from different Member States. It was left to the Member States to provide for rules that facilitated a merger of an SCE with a cooperative society from another Member State and vice versa. ${ }^{32}$ However, the 10th Directive did not create the facility for cross-border mergers between cooperatives from different Member States.

In summary, the lack of success of the SCE is caused by a lack of awareness of this cooperative form, the complexity of the SCE Regulation and the necessary implementation measures, the mandatory and complex rules for employee involvement and the absence of a specific tax regime. Combined, it makes the SCE highly impractical, whereas at the same time it is not self-evident what the specific benefits of the SCE Statute are in practice vis-à-vis national cooperative statutes. Switching costs are persuasive. However, since the SCE Statute exists and 25 SCEs have been established and a revision is not likely to be initiated by the European Commission, cooperatives and their incorporators continue to use national cooperative laws - legislative immobility and inertia in this respect prevail.

30. Similar conclusions were drawn in Euricse/Cooperatives Europe/Ekai (2010), Study on the implementation of the Regulation 1435/2003 on the Statute for European Cooperative Society, 5 October 2010 and Fici 2013b, pp. 115-151.

31. Directive $2005 / 56 / E C$ on cross-border mergers of limited liability companies, OJ L310/1 25 November 2005.

32. See Art. 3, para. 2, 10th European Company Law Directive.

\section{General Features and Efficiency of National Cooperative Laws in the EU}

From the account so far, we conclude that contrary to its objective the SCE Statute did not approximate the national cooperative laws of the Member States. Nor did it provide an efficient legal business form used by cooperatives that operate on cooperative principles as defined by Dunn. ${ }^{33}$ This raises the question how efficient national cooperatives laws are in this respect. In the 2012 EU-wide research project Support for farmers' cooperatives, this question has been addressed. In particular, the legal environment for farmers to set up and maintain cooperatives was part of several studies, amongst which a study to identify and analyze policy measures and instruments in the Member States that promote or impede the creation and functioning of agricultural producer organizations, notably cooperatives, from a legal point of view. ${ }^{34}$ The study made an effort to assess the effectiveness of the current legal environment, focusing on business organizational law, competition law and tax law issues. Although national cooperative laws and the legal environment with adjacent policy measures differ strongly between Member States and even in some Member States within regions, from a business organizational point of view the end-users of the cooperative - farmers - in this study were rather positive on the merits of how cooperatives have been regulated, although on several issues improvement could be achieved in several Member States. ${ }^{35}$ Below, the most important results and conclusions of this study are presented, assessing ten hypotheses. ${ }^{36}$

Hypothesis 1. The current legal regulation is

hampering the formation of cooperatives

Although there is no evidence that Member States actively promote the formation of cooperatives to organize agricultural producers nor mandate that they should incorporate into a cooperative, the cooperative is com-

33. Dunn 1988. Dunn developed three basic principles while defining cooperatives: (1) The user-owner principle, meaning that those who own and finance the cooperative are those who use the cooperative; (2) The user-control principle, meaning that those who control the cooperative are those who use the cooperative; and (3) The user-benefit principle, meaning that the sole purpose of the cooperative is to provide and distribute benefits to its users on the basis of their use.

34. Van der Sangen 2012b.

35. The methodology to assess the effectiveness of the current legal environment included an inventory of policy measures and inducements in all Member States through separate country reports as well as an inventory of positive and negative legal drivers in practice through questionnaires to be answered by selected national experts on cooperative law, while cross-checking the results with the data available in the 2010 Study on the implementation of the Regulation 1435/2003 on the Statute for European Cooperative Society, 5 October 2010 of Euricse/ Cooperatives Europe/Ekai.

36. This section is taken from the conclusion of Van der Sangen 2012b, pp. 43-46. The data were collected from Member States through a questionnaire on legal aspects, a country report and an inventory of policy measures. 
monly used in the EU in agriculture and appears to be the natural legal environment for agricultural producers to organize their joint business activities. However, the promotion of cooperatives is indirectly supported by tax facilities in several Member States. Yet, the cooperative is not commonly used by farmers in Bulgaria, Estonia, Latvia, Poland, Romania, Slovakia and Slovenia. ${ }^{37}$ The limited liability company is the dominant legal entity in which agricultural producers are organized in these Member States. In Portugal, the division is 50/50. The SCE is not used in the agricultural sector, nor did the national experts refer to it as one of the available legal business forms. The costs for setting up a cooperative as well as for maintaining a cooperative are not hampering the formation of cooperatives.

Hypothesis 2. The way cooperatives have to legally organize their internal governance is too cumbersome and hampering efficient decisionmaking

Assessing the legal structures of the internal governance of cooperatives, ${ }^{38}$ the data did not support this hypothesis. On the contrary, except for Portugal, the overall internal governance structures are viewed from a legal point of view as flexible. In large cooperatives, in particular internationally operating cooperatives with diversified activities, there may be some concern about the perceived loss of effective control by members. ${ }^{39}$ Questions were also raised with regard to the internal governance for small cooperatives, indicating that efficiency could be gained in sizing down the mandatory cooperative bodies. In 22 Member States, members did not feel an accountability gap. The accountability of the management board to members, however, was viewed as problematic in Greece, Portugal, Spain and the UK and was related to the lack of legal mandates to form a supervisory board or an equal institution. The efficiency of cooperatives as well as the monitoring of the management board could be increased through professional managers on the management board and/or on the supervisory board. In Bulgaria, Cyprus, the Czech Republic, Greece, Malta, Portugal and Slovakia, the members of the management board have to be members of the cooperative. Sixteen Member States provided the possibility to have non-members to be elected on the management board. In seven Member States, members of the supervisory board needed to be members of the cooperative. However, it does not necessarily mean that there is an accountability gap because of a lack of professionalism on the supervisory board. We assume because in these Member States the cooperatives are small and regionally operating, leaving members themselves in the position to actively monitor the management board.

37. The reason is that the concept of the cooperative in these Member States is associated with the state-owned collective farms and planning economy and resulted in a general distrust against the cooperative.

38. In this respect, reference should also be made to Bijman 2002; Bijman, Hendrikse \& Van Ooijen 2012, and Bijman \& Van der Sangen 2012.

39. Confirmed by the study of Bijman, Hanisch \& Van der Sangen 2014, pp. 641-661.
Hypothesis 3. The legal structure restricts cooperatives in their economic need to be able to depart from the principle of open membership With regard to the question whether cooperatives are legally allowed to follow a restrictive admission policy towards applicants for membership, the overall majority of Member States did not have legal obstacles to introduce additional requirements upon entrance by setting standards in the articles of association of the cooperative. Of course, certain standards may be onerous or result in an infringement of competition law, but the freedom to follow a restrictive admission policy was well established in most Member States from a business organizational point of view. However, the data on Denmark, France, Hungary and Ireland seem to suggest that the principle of open membership is legally enforceable. For Denmark, reference was made to the fact that a cooperative may have an obligation to accept new applicants, because of the dominant position of the cooperative in the market.

Directly related to the question of open membership is the question whether all members are entitled to have voting rights according to the principle of 'one man, one vote' and whether the cooperative and its existing members are free to depart from it by introducing voting rights proportional to the volume of economic transactions of the individual member. In ten Member States, the principle of 'one man, one vote' was the mandatory rule. In 11 Member States, cooperatives were allowed to depart from it, however, with a limit on the number of multiple votes, while a minority of Member States allowed departing from the principle without any limits set by law on the number of multiple voting rights. ${ }^{40}$

\section{Hypothesis 4. Cooperatives have ineffective legal mechanisms to control the continuity of the input or purchase respectively by their members because cooperatives are presumed to have ineffective tools to prevent members from withdrawal}

The hypothesis was found to be true for a significant number of Member States that adhere to the principle of voluntary membership giving the members unrestricted freedom to exit the cooperative (Cyprus, the Czech Republic, Denmark, France, Italy, Latvia, Lithuania and the UK). In the other Member States, cooperatives were allowed to introduce restrictions, showing a large variety of modes in the time frame of dismissal from the membership. Two important findings are: (1) in all Member States, the restrictions on exit were viewed as reasonable and fair, indicating that setting restrictions on exit is not considered problematic from a business organizational point of view, and (2) the existence of
40. This is an interesting point because the principle of 'one man, one vote' is not the general norm in practice when agricultural cooperatives grow and the heterogeneity among members increased. In fact, the possibility of differentiation of voting rights and its implementation is positively correlated with the overall performance of the cooperative. See Hendrikse \& Van Ooijen 2004 and Hendrikse, Liang \& Huang 2012 as well as Hanisch \& Rommel 2012 
restrictions on exit did not preclude potential members from joining a cooperative. Of course, in specific cases restrictions on the right to withdraw from the membership might be null and void because they constitute an infringement of national and/or EU competition law rules. $^{41}$

\section{Hypothesis 5. Cooperatives encounter different} types of legal constraints with regard to doing business with members from other Member States or in case business activities are organized in different Member States

No evidence was found that national cooperative statutes contained legal restrictions on the acceptance of members from other Member States or on the exercise of their membership. Taking into to account the established case law of the CJEU on the freedom of movement, ${ }^{42}$ cooperatives encounter no restrictions in setting up subsidiaries in other Member States. The SCE Statute is not used until now by agricultural producers to form a transnational or international cooperative. Questionable is whether potential members from another Member State can be barred from becoming a member if the cooperative in the other Member State is the only viable economic option to join a cooperative. The taxation of members from other Member States did not lead to significant problems so far, with the exception of the two cases reported in Sweden/Denmark and France/ Germany.

With regard to the question whether cooperatives are restricted by law to organize the cooperative as a group with the cooperative as the parent company, Member States do not impose any restrictions on cooperatives in this respect. Yet, setting up subsidiaries may have a negative impact on the taxation of cooperatives and in several Member States triggers a loss of tax facilities especially designed for cooperatives and their members to prevent double taxation. This tax aspect and also the question as to whether cooperative groups result in a loss of effective control by members need further investigation.

\section{Hypothesis 6. Cooperatives are not able to} distribute net proceeds taking into account the proportion of capital paid in by members

The key question with regard to this issue was whether the law prevented tailor-made solutions in this respect. The overall conclusion is that cooperative statutes do not restrict members to create tailor-made solutions in their article of association. It is common practice that the distribution of profits to members as well as their obligations to participate in self-financing techniques of the cooperative is executed on the basis of the principle of proportionality, according to the volume of supply or

41. See hypothesis 10 below.

42. CJEU 9 March 1999, C-212/97 (Centros), [1999] ECR I-1495, CJEU 30 September 2003, C-167/01 (Inspire Art), [2003] OJ C 275/10, CJEU 5 November 2002, C-208/00 (Überseering), [2002] ECR I-9919 and CJEU 13 December 2005, C-411/03 (Sevic Systems AG), [2005] ECR I-10805. purchase of an individual member with the cooperative. ${ }^{43}$ In this respect, it is worth mentioning that 22 Member States were reported to have flexible legal rules on the distribution of profits to its members. However, retaining profits and accumulating reserves may trigger a loss of tax facilities. ${ }^{44}$

Hypothesis 7. The legal structure of cooperatives prevents cooperatives from raising sufficient equity from outside investors

A remarkable result is that the virtual absence of raising equity from outside investors is not caused by the lack of an adequate legal structure. Only seven Member States (Belgium, Bulgaria, Cyprus, Estonia, Portugal, Romania and Slovakia) did not allow outside investors to participate in the equity capital of the cooperative. Accordingly, in these Member States voting rights could not be adjudicated to non-using members. However, it remains questionable whether in these Member States there is a genuine demand for this legal facility. The other Member States allowed or did not forbid outside investors to participate in raising equity. However, in a substantial number of these Member States this facility was not aligned with the adjudication of voting rights to outside investors (Finland, Greece, Hungary, Latvia, Lithuania, Malta, Poland, Slovenia, Sweden and the UK). But, even in the Member States with both facilities, raising equity from outside investors finds itself in an embryonic stadium. ${ }^{45}$ Hence, the conclusion that the legal structure of cooperative is not a dissuasive factor in this respect. ${ }^{46}$

Hypothesis 8. Cooperatives lack a proper legislative structure to reorganize their business, amongst others by way of legal mergers at a national or European level

With regard to domestic merger facilities, the overall view is that all Member States do have facilities for cooperatives to merge with other cooperatives, although there was no mandate to do so based on the Third EU Company Law Directive on the harmonization of domestic legal mergers for limited liability companies. With regard to the question as to whether cooperatives have efficient facilities to merge with other legal business forms, Bulgaria, Ireland, Luxembourg, Poland, Portugal, Romania and Slovakia precluded this option. On the other side, Austria, Belgium, Germany, Hungary, Greece, Lithuania and Spain provide a highly flexible set of rules on domestic mergers. The largest group of Member States provides for rules on domestic

43. See Van Bekkum 2009 and specifically for the Netherlands: Van der Sangen 2012a, pp. 438-449.

44. See hypothesis 9 below.

45. See for an overview Bijman, Hanisch \& Van der Sangen 2014, p. 654.

46. This is confirmed by studies on cooperatives and equity raising through stock markets. This is not to say that taking this route is unproblematic, since it evokes discussions on the nature of the cooperative and its strategy as a cooperative enterprise, but from a legal point of view several Member States, like Finland, France, Germany, Ireland and the Netherlands, do not impose unsurpassable legal barriers in this respect. See Van Bekkum \& Bijman 2007, pp. 34-56. 
mergers between cooperatives and with private companies, although with several highly path-dependent restrictions. In this respect, the situation in Spain is interesting because there are some impediments for cooperatives from different autonomous regions to merge with cooperatives of another region. Also, in general the efficiency of reorganizations is not negatively affected by rules of employee involvement or taxation vis-à-vis investor-owned firms.

The facilities for cross-border mergers between cooperatives from different Member States, however, remain fragmented. The SCE Regulation provides the necessary facilities for cross-border mergers, but - as discussed above - the SCE is not used in practice by agricultural cooperatives. The 10th EU Company Law Directive on cross-border legal mergers of private companies did not have a significant harmonizing effect on the facilities for cooperatives to engage in a cross-border merger. Although the right to participate in a cross-border legal merger between cooperatives from different Member States can be based on ECJ case law, notably the Sevic System AG-case, ${ }^{47}$ this possibility lacks legal certainty. Future research should address the question whether relaxing the 10th Directive would be a viable option to facilitate cross-border mergers of cooperatives.

Hypothesis 9. Cooperatives have been granted too little leeway in tax law to circumvent the negative effects of the distribution of net proceeds

With regard to the question whether tax law prevented double taxation in a manner that would be more burdensome for cooperatives than for IOFs, the results can be divided into three groups of Member States. Greece, Latvia, Malta and Portugal effectively exempted cooperatives from the application of corporate income tax. ${ }^{48}$ On the other side of the spectrum, there are eight Member States (Bulgaria, the Czech Republic, Estonia, Finland, Ireland, Lithuania, Poland and Slovenia) with no special tax facilities for cooperatives, and 4 Member States (Italy, Romania, Slovakia and Spain) with tax facilities that did not have a significant impact on the promotion or success of the cooperative. The taxation of cooperatives and their members vis-à-vis IOFs has been labelled in the questionnaires as not being reasonable and fair in Hungary, Italy, Lithuania, Poland, Romania, Slovakia and Spain. In Hungary, Lithuania, Poland, Romania and Slovakia, because there is no level playing field, while in Italy and Spain the tax facilities are insufficient given other costs incurred by the cooperative. I-10805.

48. However, in Belgium as well as in Italy a certain type of cooperative with a social dimension has been granted exemptions from corporate income tax. See for Belgium: Coates 2013, pp. 255 and 265, and for Italy: Fici 2013a, pp. $496-498$ as well as Joined Cases C-78/08 to C0-80/08 Ministero dell'Economia e della Finanze v. Paint Graphos Sarl, 8 September 2011
Hypothesis 10. Cooperatives have been granted too little leeway in competition law in order to fulfil their economic objective as countervailing power or to gain economies of scale

Although cooperatives in all Member States are submitted to rules of national and European competition law, competition law only appears to be relevant for cooperatives from the Czech Republic, Denmark, Finland, Germany, Ireland, Luxembourg, the Netherlands, Poland and Sweden, and to some extent France and the UK. In the other Member States, the cooperatives' market share is too low or members were entitled to withdraw without significant restrictions. For the first group of Member States, reference was made to a dominant market position of one or more cooperatives. This overview underscores that cooperatives in agricultural sectors are very diverse in their economic nature, size and market share. What is important, however, is that cooperatives are not generically exempted from the application of competition law, although for agricultural producer organizations, including cooperatives, there are some specific exemptions envisaged in EU Law. ${ }^{49}$ According to the final report Support for farmers' cooperatives, ${ }^{50}$ cooperatives are on the radar of national and EU competition authorities, and probably this will intensify with future mergers. In this study, cooperatives have reported to experience legal uncertainty in the application of competition law resulting in high costs due to the burden of proof. A future research question put forward in the final report was whether and how elements of the US system of anti-trust exemption for cooperatives under the Capper Volstead Act could be incorporated usefully in the EU legal frameworks of Articles 101-106 TFEU, the specific rules for the agricultural sector, the Common Agriculture Policy and the national competition rules. ${ }^{51}$

\section{Sources of Path Dependency}

The overview of the general features and efficiency of national cooperative laws in the EU already gives us an indication of the high degree of diversity of legal regulations of the cooperative in EU Member States related to the diversity of historic origins of the cooperative and its legislation. It should be pointed out that the historic development of legislation on cooperatives is complex and path-dependent, leading to a large degree of differences between Member States' legal regulations of the cooperative as a legal business form. At the same time, we saw that the EC has not actively attempted to approximate the national laws of its Member States with

49. Regulation $1184 / 2006$ (EC) applying certain rules of competition to the production of and trade in agricultural products, and Regulation (EC) $1234 / 2007$ establishing a common organisation of agricultural markets and on specific provisions for certain agricultural product.

50. Bijman et al. 2012, p. 119.

51. For a concise overview of EU competition rules applicable to cooperatives and producer organizations in the agricultural sector, see Van der Sangen 2012b, pp. 29-38, as well as Gerbrandy \& Vries 2011 
regard to the laws and regulations on cooperatives. ${ }^{52} \mathrm{We}$ also came to the conclusion that with regard to cooperatives, there is no established acquis communautaire similar to the EU company law harmonization programme. ${ }^{53}$ With respect to the approximation of the national cooperatives statutes, it should be noted that - as community law stands to date - the European Commission has no exclusive authority to put forward proposal for the approximation or harmonization of cooperative law of the Member States as new proposals will be subject to the principles of subsidiarity and proportionality. Nevertheless, the proclaimed objective of the SCE Regulation was considered - amongst others - to provide an instrument to indirectly approximate the national laws on cooperatives in EU member states. ${ }^{54}$ The legal basis of the SCE Statute had been contested before the CJEU, but according to the CJEU the authority of the EC to put forward the SCE Regulation has been correctly based on the former Article 308 EC Treaty. ${ }^{55}$

Although one of the SCE Regulation's objectives was to indirectly approximate the law on cooperatives of the Member States and the EC's authority could not be scrutinized before the CJEU, recent research on the implementation of the SCE Regulation into the national laws of the members states has demonstrated a very trivial effect in this respect. ${ }^{56}$ This conclusion is contrary to the explicit objectives of the SCE Statute: not only to indirectly approximate the national cooperative laws but also to increase competition between the 'national' SCE and national cooperative forms in being the most efficient instrument to organize a cooperative business activity, which - according to the High Level Group could lead, potentially, to a lack of balance between national legal forms of cooperatives and the SCE. ${ }^{57}$ As said, empirical studies have not revealed any vertical competition between national cooperatives and the SCE Statute in favour of the SCE. ${ }^{58}$ Future attempts to regulate cooperatives will be burdened with the diversity of national cooperative laws, including their implementa-

52. The 2003 EU Corporate Governance Action Plan, $\operatorname{COM(2003)} 284$ of 21 May 2003, under para. 3.6 is inconclusive on the matter.

53. See the 2003 EU Corporate Governance Action Plan, COM(2003) 284 of 21 May 2003, under para. 1.1.

54. See the EC Communication $\operatorname{COM}(2004) 18$, pp. 10 and 11. In the same vein: Report of the High Level Group of Company Law Experts on a Modern Regulatory Framework for Company Law in Europe (Winter Report), 4 November 2002, Chapter VIII, section 1: “The approach for the SCE has been to take advantage of the substantial work developed in the harmonisation of company law to the extent company law rules do not conflict with the peculiar traits of cooperatives. The long list of articles that call for the application of company law rules shows that the Company Law Directives can be used as instruments to complete many aspects of the Regulation on the SCE." However, the starting point of analysis should not be company law but the economic nature of cooperative enterprises.

55. CJEU 2 May 2006, C-436/03 (European Parliament vs. Council of the European Union), ECR I-3733.

56. See Study on the Implementation of the Regulation 1435/2003 on the Statute for European Cooperative Society, 5 October 2010, pp. 78 and 79.

57. High Level Group on Company Law Experts, Chapter VIII, section 1

58. The 2010 SCE-Study. See on the concept horizontal regulatory competition Roe 2003, p. 588 as well as Levmore 2010, p. 62. tion of the SCE Statute, as well as with the history of the SCE Regulation and Directive as an EU legislative product. Although inefficient, the SCE Statute in itself will remain a rule-driven source of path dependency.

A second source of path dependency - in the terminology of Bebchuk and Roe tending more towards structure driven than rule driven - is the ambiguity towards the objective of the concept of the cooperative and its legal construct which is highly connected to the question whether cooperatives should encapsulate ideology and social norms. This position is advocated by the International Co-operative Alliance (hereinafter ICA). According to the ICA, a cooperative is an autonomous association of persons united voluntarily to meet their common economic, social, and cultural needs and aspirations through a jointly owned and democratically controlled enterprise. Cooperatives should be based on the values of self-help, self-responsibility, democracy, equality, equity and solidarity. According to the ICA, cooperative members believe in the ethical values of honesty, openness, social responsibility and caring for others. The ICA has set up seven cooperative principles as guidelines by which cooperatives put the aforementioned values into practice. These principles include: (1) voluntary and open membership, (2) democratic member control, (3) member economic participation, (4) autonomy and independence, (5) education, training and information, (6) cooperation among cooperatives and (7) concern for community. Although the principles of the ICA are frequently referred to by policymakers, ${ }^{59}$ the principles have no legal binding status since European or national legislators are not obliged to adhere to these principles, nor do they have an obligation to actively implement these principles into binding legal rules.

The official position of the European Commission (hereinafter EC) on the issue is that the EC does not actively promote the implementation of the ICA cooperative principles. ${ }^{60}$ Although societal and ideological aspects currently may have been included in the European and Member States' legislature, ${ }^{61}$ the overall denominator for the cooperative is that a cooperative is primarily viewed by its members and the European and national legislature as an enterprise that meets the three characteristics of user-ownership, user-control and user-benefit. The quintessential characteristics of a cooperative as a user-owned, user-controlled and userbenefit enterprise in particular apply to the case of agri-

59. See Resolutions of the United Nations, the ILO and the European Commission.

60. See Communication from the Commission to the Council and the European Parliament, The European Economic and Social Committee and the Committee of Regions on the promotion of cooperative societies in Europe, $\operatorname{COM}(2004)$ 18, Brussels, 23 February 2004, stating: "The Commission invites Member States to be guided, when drafting national regulations governing cooperatives, by the 'definition, values and cooperative principles' of the above mentioned Recommendations but also to be sufficiently flexible in order to meet the modern needs of cooperatives". The recommendations referred to are the ILO recommendations that fully incorporate the ICA cooperative principles.

61. A good example is Belgium that offers two types of cooperatives, one with a social dimension facilitated by supporting tax rules and one neutral cooperative society. 
cultural cooperatives as the legal entity for their joint economic activities. Commonly, agricultural producer organizations are organized as cooperatives and operate from a legal point of view as separate legal entities with legal personality. However, other legal business forms are available as well to organize agricultural producers, as an EU-wide study on the legal aspects ${ }^{62}$ has demonstrated. In this respect, it is worth noting that the existing legal definitions of cooperatives do not reflect the aforementioned principles or only partially. At the same time, it is debatable whether legal definitions of the cooperative are meant to reflect the ICA principles, for this goes beyond the scope of the objectives of company law or business organizational law. ${ }^{63}$ It is understood in legal scholarship that company law should facilitate different types of entrepreneurial activities by providing flexible default model statutes of legal entities that meet the demands of the average end-users - in our case, for example, the agricultural producers as the promoters of the cooperative - while at the same time providing standardized solutions to protect minority shareholders/members and to prevent abuse of the corporate form towards creditors and employees. ${ }^{64}$ The encapsulation of ideological and societal objectives into the corporate statute is not the primary function of company law regulation. ${ }^{65}$

However, it is apparent that the way the organizational business form 'cooperative' has been defined in the past reflects the difference in attitude of legislators, policy makers and interest groups and co-operators. The economic, social and ideological definition of the cooperative represents different approaches towards the nature and societal function of the cooperative. For example, according to the ICA, ILO and the UN that represent a more ideological approach, cooperatives are defined as follows: "A co-operative is an autonomous association of persons united voluntarily to meet their economic, social, and cultural needs and aspirations through a jointly-owned and democratically-controlled enterprise." It is arguable whether the social, ideological and cultural aspects proclaimed as an objective of the cooperatives have been encapsulated into the legal definitions of cooperative law in jurisdictions worldwide.

A common economic definition of the cooperative provided by Emelianoff is, for example: "Cooperative organizations represent the aggregates of economic units. (...) The true nature of such agency can be thoroughly understood only if we clearly keep in mind that the cooperative represents the associated economic units in their functioning and not their association as a sepa-

62. Van der Sangen 2012b.

63. See on the function of company law regulation McCahery \& Vermeulen 2008 and Essers et al. 2011. Referring to the situation in the Netherlands, the Dutch legislator explicitly refrained from adding ideological or societal objectives in the legal definition of the cooperative and made an economic assessment of the cooperative while regulating the cooperative as a legal person. See Van der Sangen 1999.

64. See Kraakman et al. 2009.

65. This is not to say that legal persons are not mandated by different sets of norms of social responsibility, but it is debatable whether this should be achieved through company law regulation. rate economic entity." 66 In this view, the cooperative represents a form of incomplete vertical integration and represents an organizational solution to market failure. ${ }^{67}$ Legal definitions of the cooperative as a legal business form across jurisdictions worldwide reflect these different approaches. For example, in the legal definition of the cooperative in the Netherlands and Germany no reference has been made to another objective than to the economic objective of the cooperative. Article 53, section 1, Second Book, Netherlands Civil Code defines the cooperative as follows: "A cooperative is an association established as a cooperative by virtue of a notarial deed. Under its articles of association, its statutory objective must be to provide for certain material needs of members under agreements, other than insurance agreements, concluded with them in the business its conducts or causes to be conducted to that end for the benefit of its members." First and foremost, the cooperative according to Dutch law is mandated to run an enterprise aligned and ancillary to the economic interests of its members. Contrarily, Belgium has regulated two types of cooperatives - one with a social and ideological objective, granting the members certain tax facilities, the so-called accredited cooperatives, and one with a purely economic objective.

The SCE Statute clearly comprises both approaches and states ambiguously in Article 1, section 3, SCE Reg: "An SCE shall have as its principal object the satisfaction of its members' needs and/or the development of their economic and social activities, in particular through the conclusion of agreements with them to supply goods or services or to execute work of the kind that the SCE carries out or commissions." The legal objective of the SCE must be achieved in compliance with the following principles that are evidently inspired by the ICA principles (see preamble statement 10 to the SCE Statute), amongst which: "net assets and reserves should be distributed on winding-up according to the principle of disinterested distribution, that is to say to another cooperative body pursuing similar aims or general interest purposes." This is not what ordinary farmer members expect when they have a vested economic interest in their agricultural cooperative. The cooperative is first and foremost, though collectively owned, a privately owned business form. ${ }^{68}$

From these examples, which can be easily extended, follows a high degree of differences in how legislators

66. Emelianoff 1942, p. 72.

67. More information about the economic functions of cooperatives can be found in Hansmann 1996 and Ollila 2009.

68. The question is, however, how legislators could actively promote the social and ideological dimension of the cooperative movement. In my view, not by interfering in cooperative charters that are tailored primarily for economic reasons, because a cooperative is a voluntary, privately held legal person in which the rules are set by the incorporators upon first establishment and later by the members through adjustments of the articles of association. It is also true that this type of cooperative with an economic objective may include societal effects of solidarity, network building, trust and education of members, capacity building and the development of regions. See Bijman et al. 2012, pp. 83-100. In the same vein: Gijselinckx \& Bussels 2014, pp. 509-530 and Hagendorn 2014, pp. 555-577. 


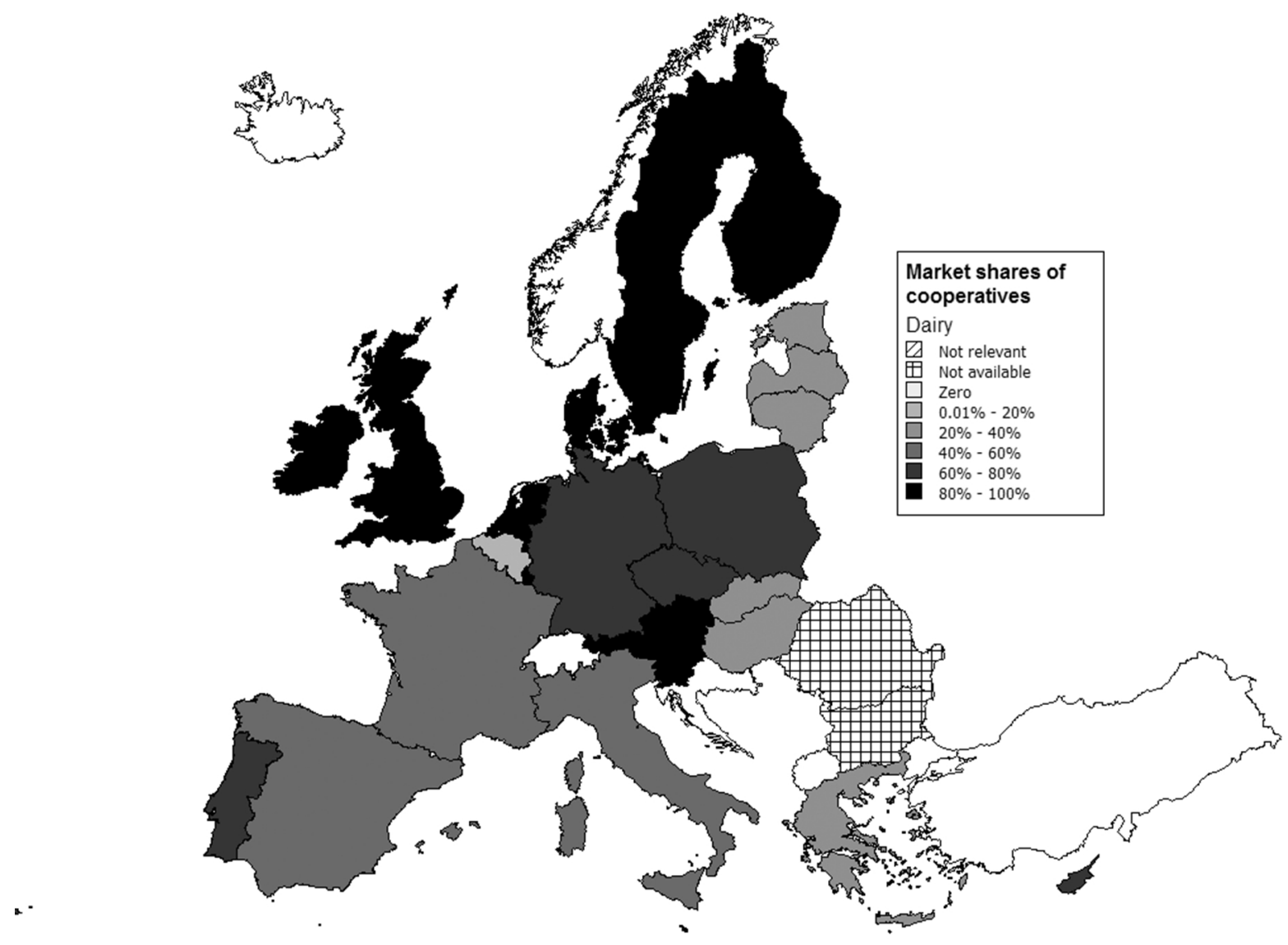

define the cooperative as a legal business form. According to Fici, the only common denominator for all legal definitions under investigation that formed the basis for the International Handbook of Cooperative Lam (2013) is that a cooperative has a variable capital base, including the total absence of a capital base. Hence, what has been expected, but only recently thoroughly documented, is the existence of a high degree of path dependency, not only worldwide but also within the European Union. To a large extent, this high degree of path dependency is structure driven.

The high degree of differences in defining the cooperative as an ideological, economic or legal construct or institution clearly sets a problem for legislators: how to establish and fix the societal function of the concept 'cooperative' and to translate it into a legal construct? The first wave of cooperative law legislation started in England, but the pace, the origins and the perception of the legislator were quite different, even in what was considered the developed industrial Western Europe in the second half of the nineteenth century. In the initial stage, the cooperative moment in England was more consumer oriented, Germany and the Netherlands more farmer oriented, and France, Italy and Spain more worker oriented. This source of path dependency is structure driven, for it relates to the initial ownership structure of cooperatives that had a predominant influence on the type of laws and norms applied to this type of company. As stated above, the result was an endemic growth of cooperatives as legal persons and corresponding cooperative statutes, embedded in the existing private law structures of a specific country. These differences are felt until today: in some jurisdictions of the EU, the cooperative is viewed as an association - with or without mandatory, though variable, capital base - in others as a society or as part of contract law, while in some other EU Member States cooperatives have no separate legal statute, like in Denmark and the UK.

The differences in their respective legal history and the way the cooperative as a legal business form has been integrated into existing private law and/or company law provide a strong case of path dependency. Any future regulation at EU level will have to overcome these differences. However, regulating cooperative activities present three additional problems. The first problem relates to the economic objective of the cooperative. Although cooperatives in all Member States are viewed as separate legal persons - distinct from its members the true economic nature of the cooperative - as illustrated by Emelianoff - can only be understood and measured in conjunction with the economic interests of the households of its members, for the cooperative is an ancillary business form without an own economic interest to maximize profit. However, cooperatives may develop and grow and take up business activities unrelated to the patronage relationship with its members. From a legal point of view, the difference between a purely ancillary and a diversified, non-ancillary cooper- 
ative is relevant in tax law ${ }^{69}$ and to some extent in competition law. ${ }^{70}$ The second problem is that cooperative entrepreneurship is not confined to the legal business form of the cooperative. As already indicated, cooperatives are allowed to be organized as cooperative groups with domestic and foreign subsidiaries, but in practice we may also find cooperative organizations that use a different legal business form. The problem is that the first may be less a cooperative than the latter. ${ }^{71}$ The third problem is that while regulating and promoting cooperative activity, positive inducements and incentives to establish a cooperative may attract other noncooperative end-users that use the cooperative as an artificial tool, like the recent practice in the Netherlands to use the legal business form of the cooperative as a special purpose vehicle in tax planning to avoid the payment of Dividend Withholding Tax and Corporate Income Tax. $^{72}$

From a macro-economic view, there are also several structure driven sources of path dependency. For example, in the report Support for Farmers' Cooperatives (2012) the differences in market share of cooperatives have been described in general terms but also in respect of sectorial, regional and geographical dispersion. This may be illustrated by looking at the market share of cooperatives in the dairy sector across Member States of the EU (see Figure 1).

The economic differences are immense. What is more important is that cooperatives themselves vary among jurisdictions with regard to their relative position in the lifecycle of a cooperatives organization as well (see Figure 2) ${ }^{73}$ Taking the differences in market share into account as well as the differences in the lifecycle of the cooperatives, giving specific sector-related negative or positive drivers, uniform top-down law-making for all cooperatives in the EU cannot take into account all these differences. For example, existing cooperatives in the agricultural sector had no benefit from the SCE Statute: large transnational and international cooperatives did not switch to the SCE Statute because they already invested and mastered tailoring their cooperatives charters to their specific needs, while for small cooperatives the SCE Statute was ostensibly too complex and surrounded with legal uncertainty, while they require a basic, non-complex cooperative charter. While the large cooperatives are able to contract for more efficient rules, small cooperatives are not in the position to contract for

69. For example, profits of cooperatives generated from transactions unrelated to the patronage of the cooperative are in most jurisdictions that provide exemptions for cooperatives from Corporate Income Tax, taxed in a similar way as investor-owned firms.

70. For example, first stage processing cooperatives in the agricultural for certain agricultural products may be exempted from EU-antitrust rules.

71. For example, international cooperatives having production facilities without member patronage but through non-member farmers supplying the production do not invite these suppliers to become members, because the existing members are reluctant to renegotiate their ownership rights. See Bijman et al. 2012, p. 113

72. Nillesen \& Van den Hurk 2012, pp. 430-437.

73. For more information on international cooperatives in this respect: Van Bekkum 2009. tailor-made cooperative charters. A lack of professionalism of members and boards, lack of legal knowledge and education may be important factors, especially in the former Eastern European Member States and in certain underdeveloped regions. ${ }^{74}$ The SCE Statute in this respect was the wrong policy tool but is likely to influence as a path-dependent factor future policy making at EU level.

\section{How to Provide for Efficient Corporate Charters for Cooperatives?}

From the analysis in section 4 of this article, we conclude that in several Member States much is to gain in revising national cooperative law. Important issues to be dealt with are related to the flexibility of the internal governance, the possibility to differentiate in voting rights and the distribution of net proceeds, the possibility to introduce a non-using investor membership and the possibility to appoint professionals being non-members on the board of directors and/or the supervisory board. Also in several Members States the position of cooperatives and their members from a tax law and competition law point of view could be improved. This raises the question how efficient corporate charters for cooperatives may be provided for. Looking at company law, in particular for listed and privately held firms, there are several vectors that induce jurisdictions to change their corporate charter more efficiently. ${ }^{75}$ These vectors, however, are to a large extent non-existent as far as cooperatives are concerned. For example, cooperatives generally do not attract equity capital from capital markets and there is no market for corporate control of cooperatives, which could lead to a certain degree of convergence. There is no evidence for the existence of a market for corporate charters for cooperatives like there is to some extent for corporate charters in the EU with regard to private companies, although in theory incorporators wishing to establish a cooperative in a specific jurisdiction may select a cooperative statute from another Member State based on the freedom of movement. There are no cases of reincorporation of existing cooperatives through cross-border seat transfers. Even crossborder mergers between cooperative are rare. Since there is no regulatory arbitrage for efficient cooperative charters, the pressure for national legislators to actively compete for better national cooperative charters is likely to be weak. Also, an effective harmonization programme with regard to cooperatives in the EU is absent, while the SCE Statute did not fulfil its objective to approxi-

74. Support for Farmers' Cooperatives 2012, pp. 113 and 114.

75. Essers et al. 2011, p. 189. 


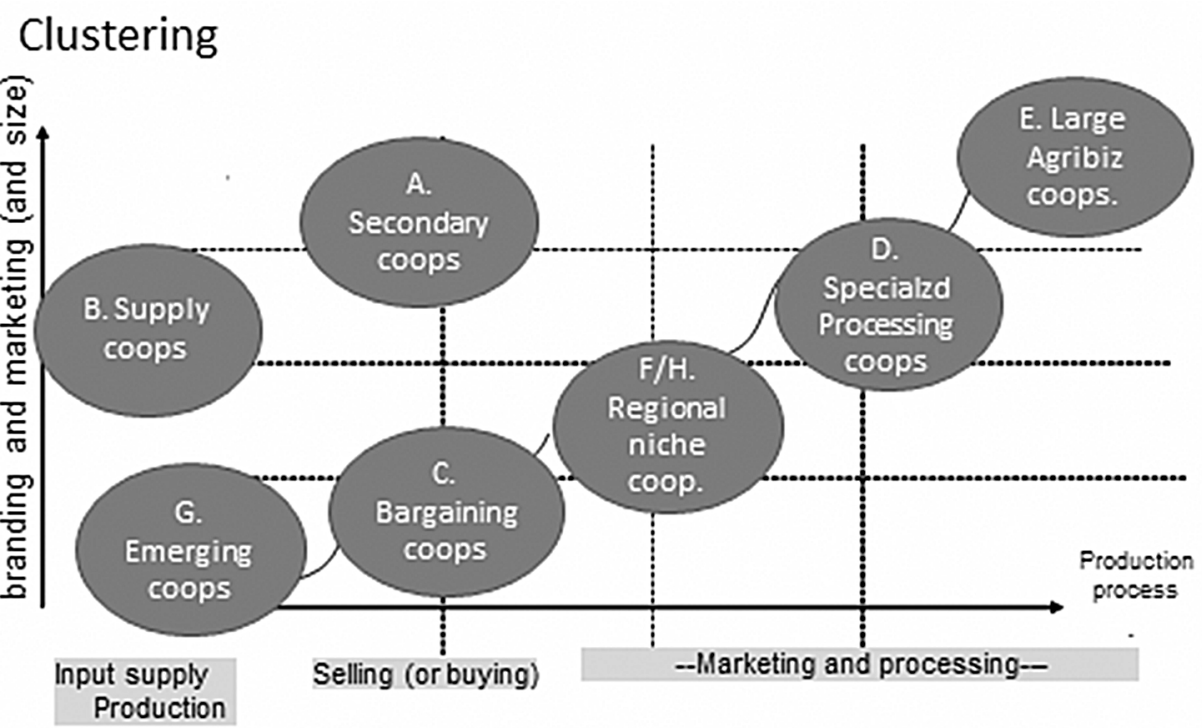

Clustering of 500 European Cooperatives, clustered on characteristics (excluding region and policies of the region relevant for those coops)

mate national cooperative law. ${ }^{76}$ The SCE in itself is a path-dependent factor and has proven to be an inefficient set of rules for cooperatives. Another vector could be the generally accepted efficiency of codes or model statutes, like corporate governance codes for listed firms. However, here again it is highly questionable whether the SCE Statute will be able to live up to the task to serve as a model statute, since knowledge about and acceptance of the statute amongst legal advisors and end-users - cooperative members - is virtually absent.

Promoting the use of cooperatives trying to provide for more efficient business organizational rules by reforming cooperative laws is an uncertain path. ${ }^{77}$ The efficiency of a top-down approach at EU-level, like the SCE Statute, has been questioned in this article. This raises the question whether Member States are allowed to introduce financial inducements for cooperatives in the form of subsidies or tax facilities other than provisions to prevent double taxation for cooperatives in general. These inducements may constitute an infringement of the state aid rules as set out in Articles 107-109 TFEU. ${ }^{78}$ Cooperatives and other producer organizations are not generically exempted from these rules.

The general rules for state aid can be summarized as follows. A support measures constitutes forbidden state aid if the following criteria are met cumulatively: (1) the support measure is taken by the state or financed by state resources, (2) the support measure (potentially)

76. A minor effect was noted in the Study on the implementation of the Regulation 1435/2003 on the Statute for European Cooperative Society, 5 October 2010, Euricse/Cooperatives Europe/Ekai, p. 151, referring to the revision of national cooperative law in relation to the implementation of the SCE Statute into national law in five member statutes. From the data, the largest revision of national cooperative laws were in Germany and Italy, although it is debatable whether these changes are fundamental and whether the revision was caused by the SCE Statute or already envisaged.

77. This section correlates strongly with Van der Sangen 2012b, § 5.4 .

78. Stevens 2010, pp. 156-169; Sánchez Rydelski 2010, pp. 149-155. affects trade between Member States and distorts competition, (3) the support measure leads to an advantage, (4) the advantage only benefits a specific group of enterprises or production ('selectivity') and, finally, (5) the support measure does not fall within the scope of any exemption provided for on the basis of the Treaty (generic exemptions as mentioned in Article 107, paragraph 2 TFEU, and specific exemptions as listed in Article 107, paragraph 3 TFEU and to be decided upon by the European Commission). The latter includes the de minimis rule: any support measure that does not exceed the total amount of $€ 200.000$, in a time frame of three years, is not considered to affect competition and constitutes, therefore, no forbidden state aid. ${ }^{79}$ For agricultural cooperatives, there are some additional specific exemptions. ${ }^{80}$

The data collected in the study Support for Farmers' Cooperatives (2012) detected several support measures specifically designed for agricultural producer organizations and cooperatives, amongst which several tax facilities in various countries, that, at first sight, might fall within the scope of state aid regulation. For example, Austria, Belgium, Bulgaria, France, Germany, Greece, Hungary, Italy, Lithuania, Luxembourg, Poland, Portugal, Romania, Spain and the UK - 15 out of 27 Member States - provide specific exemptions from taxation rules specifically designed for agricultural producer organizations or agricultural cooperatives, varying from exemptions of certain aspects of Corporate Income Tax to Property Tax or Real Estate Tax. Also, in some cases support measures in the form of subsidies for transport costs (Bulgaria and Spain) were reported.

Although agricultural cooperatives are not generically exempted from the application Article 107 TFEU, it is

79. See Commission Regulation (EC), No 1998/2006 of 15 December 2006 on the application of Articles 87 and 88 of the Treaty to de minimis aid.

80. See <http://ec.europa.eu/agriculture/stateaid/leg/index_en.htm\# specific $>$. 
not to say that the specificity of cooperatives is irrelevant, for the economic role and function of cooperatives - as well as agricultural producer organizations - has been acknowledged by the European Commission as well as the Court of Justice of the European Union. In this respect, we refer for example to the 15 December 2009 decision of the European Commission vs. Spain (C 22/01). ${ }^{81}$ The Commission acknowledged in its decision that agricultural cooperatives fulfil the objectives referred to in Article 39 TFEU and that they therefore facilitate the development of agricultural activity. Moreover, as agriculture is a sector closely linked to the economy as a whole, it must also be concluded that agricultural cooperatives facilitate the development of the economic regions where they are located.

Another positive sign with regard to the position for cooperatives in general is the recent judgment of $8 \mathrm{Sep}-$ tember 2011 of the Court of Justice of the European Union in the Joined Cases C-78/08 to C-80/08. ${ }^{82}$ This case specifically addressed the issue of selectivity, in particular with regard to tax measures, which have to be compared with a Member State's normal tax regime in order to determine whether the tax measure discriminates between economic operators who are actually in a comparable factual and legal situation given the objective of the national tax system. In this case, the use of net profits to assess corporation tax applied to cooperatives and to other firms, but the cooperatives had the benefit of exemptions not available to other firms because of their legal form. The legal issue to be decided by the court was whether the cooperatives were in a comparable factual and legal situation to the other firms. The CJEU ruled that in principle the cooperatives in these cases were not in a comparable situation and so the tax exemptions could be justified. This was because in these cases, they operated for the mutual benefit of their members who are users, suppliers or employees who benefit in proportion to their transactions with the cooperative, being a worker cooperative. In addition, the cooperatives' limited access to equity markets and the limited return offered on share and loan capital makes it harder for this type of cooperative to raise capital. The lower profit margin that flows from those characteristics makes their position not comparable with that of commercial companies. However, societies which do not truly pursue an objective based on mutuality in accordance with the EU Commission Recommendation on the promotion of cooperative societies in Europe of 23 February 2004, COM(2004) 18 final, would be treated differently and might be regarded as being comparable to commercial companies so that any tax benefit could amount to a state aid. The CJEU also explicitly referred to the recitals 8 and 10 of the preamble of the SCE Reg-

81. Commission Decision of 15 December 2009 on support measures implemented by Spain in the agricultural sector following the increase in fuel prices, OJ L 235/1 of 24 June 2010.

82. See Joined Cases C-78/08 to C0-80/08 Ministero dell'Economia e della Finanze v. Paint Graphos Sarl, decided on the basis of the former article 87 EC Treaty. For a more detailed description and analysis of the cases, Fici 2013b, pp. 122-125 ulation and the cooperative principles enunciated in those recitals.

The implication of this line of reasoning would be that a tax regime that favours cooperatives vis-à-vis investorowned firms need not necessarily constitute state aid as long as the members of the cooperative legally and factually act according to the cooperative principle of mutuality, with the guidance of the principles laid down in the recitals 8 and 10 of the preamble of the SCE Regulation. Cooperatives adhering to these principles seem to be granted a safe haven in respect of the application of state aid rules. ${ }^{83}$ However, future research needs to be done to establish under which precise conditions tax facilities for cooperatives do not fall within the scope of state aid. In particular, the interpretation of the concept 'mutuality' and its precise boundaries need further clarification.

\section{Conclusion}

This article focused on the harmonization of cooperative law in the European Union and analysed how cooperative laws in the EU Member States could be improved. In the introductory section, reference was made to the differences in the sociological and economic environment and circumstances in which the first cooperatives were established, having an impact on how cooperative laws in the Member States evolved. In essence, these differences are - in the conceptual framework of path dependency of Bebchuk and Roe presented in section 2 - structure driven. Since cooperatives were not an integral part of the EU company law harmonization programme, the differences in national cooperative law in the Member States continued to exist over the years and increased with the expansion of the EU to 28 Member States. A harmonizing effect - or at least the approximation of national cooperatives laws - was one of the objectives of the SCE Statute. We concluded in section 3 that this effect on national cooperative laws was rather trivial, in most Member States even absent. More importantly, the SCE has only been used occasionally but not for cross-border activities and was not able to provide end-users - existing transnational active cooperatives and incorporators - an efficient cooperative charter. On the one side, this is caused by the defects in how the SCE has been regulated - leading to a strong rule-driven source of path dependency - while on the other side existing national codes are viewed - based on facts and/ or perception - as more efficient. Section 4, however, demonstrated that in several Member States national cooperatives codes could benefit from a revision on certain aspects elaborated in that section. Section 5 gave an overview of the sources of path dependency, focusing on the ambiguity towards the objective of the concept cooperative and its legal construct: whether a cooperative should be regulated as the legal construct of an eco-

83. Similarly Fici 2013b, p. 125. 
nomic and organizational solution to market failure or whether a cooperative should encapsulate social and ideological norms and principles, similar to the ICA principles. It was demonstrated that this ambiguity is reflected in the different legal definitions in the EU as well as in the SCE Statute. In section 6, we addressed other driving forces that induce legislators to take up efficient law-making. These vectors, however, are virtually absent as far as cooperatives are concerned. Yet, in respect of giving financial inducements to cooperatives in order to enhance their development in competition with investor-owned firms, the recent position the CJEU takes towards cooperatives that operate on the basis of mutuality and according to the principles of the ICA and the SCE Statute, might help to promote the cooperative, since it sets them aside from the application of EU state aid rules. Apparently, with reference to George Orwell, some are more equal than others.

\section{Bibliography}

L. Bebchuk \& M. Roe, A Theory of Path Dependence in Corporate Omnership and Governance, Stanford Law Review, November 1999.

O.F. van Bekkum, Cooperative Champions or Investor Targets? The Challenges of Internationalization $\mathbb{E}$ External Capital, Study commissioned by Landbrug \& Fødervarer, December 2009.

O.F. van Bekkum \& J. Bijman, Innovations in Cooperative Ownership: Converted and Hybrid Listed Cooperatives, in S. Rajagopalan (ed.), Cooperatives in 21st Century. The Road Ahead, Hyderabad, India, ICFAI University Press 2007, pp. 34-56.

J. Bijman, Essays on Agricultural Cooperatives. Governance Structure in Fruit and Vegetable Chains, Rotterdam, Erasmus Research Institute of Management (ERIM), 2002.

J. Bijman et al., Support for Farmers' Cooperatives. Final Report, Wageningen, Wageningen University, 2012.

J. Bijman, M. Hanisch \& G.J.H. van der Sangen, "Shifting Control? The Changes of Internal Governance in Agricultural Cooperatives in the EU", 85 Annals of Public and Cooperative Economics 4, 2014, pp. 641-661.

J. Bijman, G. Hendrikse \& A. Van Ooijen, Accommodating Two Worlds in One Organization: Changing Board Models in Agricultural Cooperatives, Managerial and Decision Economics, 2012.

J. Bijman, P. Pyykkönen \& P. Ollila, Support for Farmers' Cooperatives. EU Synthesis and Comparative Analyses Report on Transnational Cooperatives, Wageningen, Wageningen University, 2012.

J. Bijman \& G.J.H. van der Sangen, Support for Farmers' Cooperatives. Case Study Report on Internal Governance of Cooperatives, Wageningen, Wageningen University, 2012.

A. Coates, "Cooperative Law in Belgium", in D. Cracogna et al. (eds.), International Handbook of Cooperative Lam, Berlin, Springer, 2013, pp. 251-269.

D. Cracogna et al. (eds.), International Handbook of Cooperative Law, Berlin, Springer 2013.

G.K. Dow, Governing the Firm: Workers' Control in Theory and Practice, Cambridge University Press, 2003.

Dumoulin et al., The European Company. Corporate Governance and Cross-Border Reorganisations from a Legal and Tax Perspective, The Hague, Boom Juridische uitgevers, 2005.

J.R. Dunn, "Basic Cooperative Principles and Their Relationship to Selected Practices", 3 Fournal of Agricultural Corporation, 1988, pp. 83-89.
I.V. Emelianoff, Economic Theory of Co-operation, Washington, 1942.

P.H.J. Essers et al., Reforming the Lam on Business Organizations, The Hague, Eleven International Publishing, 2011.

Ernst \& Young, Study on the Operation and the Impact of the Statute for a European Company (SE), Final Report, 9 December 2009.

European Commission, DG Competition, The interface between EU competition policy and the Common Agricultural Policy $(C A P)$ : Competition rules applicable to cooperation agreements between farmers in the dairy sector, working paper, Brussels 16 February 2010, pp. 1-31.

A. Fici, Cooperative Identity and the Lam, European Research Institute on Cooperative and Social Enterprises, Working Paper N. 023/12, 2012.

A. Fici, “An Introduction to Cooperative Law", in D. Cracogna et al. (eds.), International Handbook of Cooperative Lam, Berlin, Springer, 2013a, pp. 3-62.

A. Fici, "The European Cooperative Society Regulation" in D. Cracogna et al. (eds.), International Handbook of Cooperative Lam, Berlin, Springer, 2013b, pp. 115-151.

A. Fici, "Pan-European Cooperative Law: Where Do We Stand?", Euricse Working Paper, n. 47/13, 2013c.

M. Gelter, "Tilting the Balance between Capital and Labor? The Effects of Regulatory Arbitrage in European Corporate Law on Employees", 33 Fordham International Lam Fournal, 3, 2009.

A. Gerbrandy \& S. de Vries, Agricultural Policy and EU Competition Law. Possibilities and Limits for Self-Regulation in the Dairy Sector, The Hague, Eleven International Publishing, 2011.

C. Gijselinckx \& M. Bussels, "Farmers' Cooperatives in Europe: Social and Historical Determinants of Cooperative Membership in Agriculture", 85 Annals of Public and Cooperative Economics 4, December 2014, pp. 509-530.

K. Hagendorn, "Post-Socialist Farmers' Cooperatives in Central and Eastern Europe", 85 Annals of Public and Cooperative Economics 4, December 2014, pp. 555-577.

M. Hanisch \& J. Rommel, Support for Farmers' Cooperatives. An EU Wide Analysis of Internal Governance, 2012.

H. Hansmann, The Ownership of Enterprise, Cambridge, Massachusetts / London, The Belknap Press, Harvard University Press 1996.

G.J. Hendrikse \& A. van Ooijen, "Diversification and Corporate Governance”, in G.J. Hendrikse (ed.), Restructuring Agricultural Cooperatives, Rotterdam, Erasmus University, 2004, pp. 51-64.

G.J. Hendrikse, Q. Liang \& Z. Huang, Quality Provision and Governance Structure Variety: IOFs versus Cooperatives, Paper presented at the 2nd eRNAC International Conference on "Cooperative values in internationalized operations", Finland, Helsinki, 14-16 June 2012.

C. Iliopoulos et al., Support for Farmers' Cooperatives. Experiences of non-EU OECD Countries, Wageningen, Wageningen University, 2012

P. Kalmi, The Disappearance of Co-operatives from Economic Textbooks, Helsinki School of Economics Working Papers W-398, February 2006

R. Kraakman et al. (eds.), The Anatomy of Corporate Law, A Comparative and Functional Approach, 2nd edn, New York, Oxford University Press, 2009.

S. Levmore, "Uncorporations and the Delaware Strategy", in J.A. McCahery et al. (eds.), Private Company Law Reform, International and European Perspectives, The Hague, T.M.C. Asser Press, 2010.

J.A. McCahery \& E.P.M. Vermeulen, The Corporate Governance of Non-Listed Firms, Oxford University Press, 2008. 
J.T.L. Nillesen \& H.T.P.M. Van den Hurk, "De coöperatie in investeringsstructuren - fiscale aspecten", Ondernemingsrecht 2012-10/11, 2012, pp. 430-437.

P. Ollila, Principles of Institutional Economics. With Applications to Cooperative Enterprises, Helsinki University, Department Economics, Working Papers No. 56, 2009.

Report of the High Level Group of Company Law Experts on a Modern Regulatory Framework for Company Law in Europe (Winter Report), 4 November 2002.

M.J. Roe, "Delaware's Competition?", 117 Harvard Lam Review, 2003 , p. 588.

G.J.H. van der Sangen, Rechtskarakter en financiering van de coöperatie, Zwolle, W.E.J. Tjeenk Willink, 1999, with a summary in English (Legal Nature and Financing of the Cooperative).

G.J.H. van der Sangen, "The European Company and the Involvement of Employees", in S. Dumoulin et al. (eds.), The European Company. Corporate Governance and Cross-border Reorganisations from a Legal and Tax Perspective, The Hague, Boom Legal Publishers, 2005, pp. 169-214.

G.J.H. van der Sangen, "Grensoverschrijdende reorganisaties van coöperaties”, in R.C.J. Galle (ed.), Handboek Coöperatie, Dordrecht, Convoy Publishers, 2010, p. 982.

G.J.H. van der Sangen, "Financiering van coöperaties: tussen efficiency en fairness", Ondernemingsrecht 2012-10/11, 2012a, pp. 438-449.

G.J.H. van der Sangen, Support for Farmers' Cooperatives. An EU Wide Comparative Analysis of Legal Aspects, Wageningen, Wageningen University, 2012b.

G.J.H. van der Sangen, "Cooperative Law in the Netherlands", in D. Cracogna et al. (eds.), International Handbook of Cooperative Lam, Berlin, Springer, 2013, pp. 541-561.

M. Sánchez Rydelski, "Distinction between State Aid and General Tax Measures", EC Tax Reviem 2010-4, p. 149-155.

S. Stevens, "Tax Aid and Non-profit Organizations", EC Tax Reviem 2010-4, p. 156-169.

Study on the implementation of the Regulation 1435/2003 on the Statute for European Cooperative Society, 5 October 2010, Euricse/Cooperatives Europe/Ekai.

O. Wyman, Co-operative Bank: Customer Champion. Commercial Delivery - Co-operative Values, MMC Financial Services, report on behalf of the European Association of Co-operative Banks 2008. 